\title{
Nossa Terra
}

ANA PAULA TAVARES

CLEPUL

D

terra alheia não se cheira com as duas narinas

Provérbio umbundu

O génio do lugar soltou os ventos

histórias velhas na língua nova

dançou sobre o abismo anunciou

a vinda dos pássaros sobre as sementes

andou andou para chegar à montanha

e encontrou a formiga sangue pelo caminho

despertou as vespas disse

esta é a terra para viver com fome com frio

sem as feridas e com bastante lenha para queimar.

esta é tua terra teu chão de muitas voltas

p'ra viver e p'ra morrer

onde cabe a palavra todas as palavras nossas e as que hão-de vir

onde não existe espelho e o outro é um nós reencontrado

onde se fala a todas as portas

com a cortesia das pausas e

os arcos dos amigos à vista. 